\title{
Transitions in nirS-type denitrifier diversity, community composition, and biogeochemical activity along the Chesapeake Bay estuary
}

\author{
Christopher A. Francis ${ }^{1,2 *}$, Gregory D. O'Mullan ${ }^{2,3}$, Jeffrey C. Cornwell ${ }^{4}$ and Bess B. Ward ${ }^{2}$ \\ ${ }^{1}$ Department of Environmental Earth System Science, Stanford University, Stanford, CA, USA \\ ${ }^{2}$ Department of Geosciences, Princeton University, Princeton, NJ, USA \\ ${ }^{3}$ School of Earth and Environmental Sciences, Queens College, City University of New York, Flushing, NY, USA \\ ${ }^{4}$ University of Maryland Center for Environmental Science, Horn Point Laboratory, Cambridge, MD, USA
}

\section{Edited by:}

Marlene M. Jensen, University of

Southern Denmark, Denmark

Reviewed by:

Hongyue Dang, Xiamen University,

China

Phyllis Lam, University of

Southampton, UK

\section{${ }^{*}$ Correspondence:}

Christopher A. Francis, Department of Environmental Earth System Science, Stanford University,

473 Via Ortega, Y2E2 Bldg Rm. 140,

Stanford, CA 94305-4216, USA

e-mail: caf@stanford.edu
Chesapeake Bay, the largest estuary in North America, can be characterized as having steep and opposing gradients in salinity and dissolved inorganic nitrogen along the main axis of the Bay. In this study, the diversity of nirS gene fragments (encoding cytochrome $c d_{1}$-type nitrite reductase), physical/chemical parameters, and benthic $\mathrm{N}_{2}$-fluxes were analyzed in order to determine how denitrifier communities and biogeochemical activity vary along the estuary salinity gradient. The nirS gene fragments were PCR-amplified, cloned, and sequenced from sediment cores collected at five stations. Sequence analysis of 96-123 nirS clones from each station revealed extensive overall diversity in this estuary, as well as distinct spatial structure in the nirS sequence distributions. Both nirS-based richness and community composition varied among stations, with the most dramatic shifts occurring between low-salinity (oligohaline) and moderate-salinity (mesohaline) sites. For four samples collected in April, the nirS-based richness, nitrate concentrations, and $\mathrm{N}_{2}$-fluxes all decreased in parallel along the salinity gradient from the oligohaline northernmost station to the highest salinity (polyhaline) station near the mouth of the Bay. The vast majority of the 550 nirS sequences were distinct from cultivated denitrifiers, although many were closely related to environmental clones from other coastal and estuarine systems. Interestingly, 8 of the 172 OTUs identified accounted for $42 \%$ of the total nirS clones, implying the presence of a few dominant and many rare genotypes, which were distributed in a non-random manner along the salinity gradient of Chesapeake Bay. These data, comprising the largest dataset to investigate nirS clone sequence diversity from an estuarine environment, also provided information that was required for the development of nirS microarrays to investigate the interaction of microbial diversity, environmental gradients, and biogeochemical activity.

Keywords: denitrification, nitrite reductase, nirS, estuary

\section{INTRODUCTION}

Denitrification, the dissimilatory reduction of nitrate and nitrite to gaseous products $\left(\mathrm{NO}, \mathrm{N}_{2} \mathrm{O}, \mathrm{N}_{2}\right.$ ) under suboxic conditions, is a major biological loss term for fixed nitrogen from terrestrial and aquatic ecosystems to the atmosphere (Devol, 2008). In estuarine sediments, denitrification is capable of removing significant quantities $(>50 \%)$ of nitrate from the water column, providing a sink for nitrogen, and thereby playing an important role in ameliorating the degree of eutrophication in waters subjected to external (agricultural or urban) $\mathrm{N}$ inputs (Seitzinger et al., 2006; reviewed by Boynton and Kemp, 2008). The anaerobic oxidation of ammonium to nitrogen gas (anammox) also contributes to the loss of fixed nitrogen in aquatic systems, particularly in suboxic water columns (Dalsgaard et al., 2003; Kuypers et al., 2003, 2005; Francis et al., 2007; Lam et al., 2009; Ward et al., 2009), but anammox is thought to be less quantitatively significant in estuaries (Risgaard-Petersen et al., 2004; Trimmer et al., 2005), including the Chesapeake Bay (Rich et al., 2008). Sedimentary denitrification is supported both by nitrate diffusing from the overlying water and by nitrate produced by nitrification within the sediment (Kemp et al., 1990; Jensen et al., 1993, 1994). These coupled processes are quantitatively important in the nitrogen budgets of estuarine and continental shelf sediments (Christensen et al., 1987; Cornwell et al., 1999). Considering the tremendous importance of denitrification in estuarine systems, it is critical to understand the distribution, diversity, and biogeochemical activity of the underlying denitrifier communities within estuaries.

Because the metabolic potential for denitrification is widespread among many phylogenetically unrelated groups, including over 50 different genera, a $16 \mathrm{~S}$ rRNA-based approach is not generally appropriate for characterizing complex denitrifying communities. Instead, the functional genes encoding key metalloenzymes in the denitrification pathway have proven 
to be useful molecular markers for denitrifying organisms. In particular, nitrite reductase (NiR) catalyzes the first committed step to a gaseous product (Zumft, 1997), distinguishing true (gas-producing) denitrifiers from nitrate-respiring microbes (including those that perform dissimilatory nitrate or nitrite reduction to ammonium; DNRA). NiR occurs in two distinct forms that are structurally different but apparently functionally equivalent: NirS, containing iron (cytochrome- $c d_{1}$ ); and NirK, containing copper (spectroscopic types I and II). Due to the critical role of nitrite reductase in the dentrification pathway, the nirK and nirS genes have been most frequently targeted for molecular diversity studies in many environments, including soils (Prieme et al., 2002; Rösch et al., 2002; Sharma et al., 2005; Smith and Ogram, 2008); groundwater (Yan et al., 2003); wastewater (Yoshie et al., 2004); suboxic water columns (Jayakumar et al., 2004, 2009; Castro-González et al., 2005; Oakley et al., 2007); and coastal and marine sediments (Braker et al., 2000, 2001; Liu et al., 2003; Santoro et al., 2006). To date, however, the molecular diversity of estuarine nitrite reductase genes has only been explored in detail within a few systems (Nogales et al., 2002; Hannig et al., 2006; Dang et al., 2009; Abell et al., 2010; Mosier and Francis, 2010). Recent studies of bacterial ammonia monooxygenase subunit A $(a m o A)$ genes have revealed a pattern of ammonia oxidizer diversity correlated with salinity, as well as distinct communities in freshwater and high salinity estuarine environments (Francis et al., 2003; Bernhard et al., 2005; Ward et al., 2007; Mosier and Francis, 2008). While similar patterns might be expected for the distribution of denitrification genes along the estuary, denitrifier diversity might also be related to the distribution of suboxic environments and denitrification rates, which in turn depend on the availability of key factors like organic carbon, oxygen, and nitrate.

In the present study, we explore the distribution and diversity of cytochrome $c d_{1}$-type nitrite reductase ( $\mathrm{nirS}$ ) sequences in sediments of the Chesapeake Bay. This is the largest estuary in North America, and denitrification is a critical component of the $\mathrm{N}$ cycle, which is dominated by sediment $\mathrm{N}$ transformations. We have previously examined ammonia-oxidizing ( $\mathrm{AO}$ ) communties in these sediments (Francis et al., 2003), and the abundance and expression of key nirS-type genotypes at three sites in this estuary (Bulow et al., 2008). Here the fine-scale diversity, community composition, and phylogeny of nirS sequences at five stations were analyzed, along with in situ benthic $\mathrm{N}_{2}$-flux rates, in order to explore spatial variability in estuarine denitrifier diversity and function. The data described in this study are also significant because it represents the largest clone library-based survey of nirS sequence diversity in an estuary and the dataset has been used to develop a nirS microarray that can more efficiently investigate the interaction of microbial diversity, environmental factors, and biogeochemical activity.

\section{MATERIALS AND METHODS SITE DESCRIPTION}

The Chesapeake Bay drains a watershed of 166,000 $\mathrm{km}^{2}$ and fills a dendritic river valley system consisting of a main channel and 7 main rivers, including the Choptank River, a subestuary that contributes roughly $1 \%$ of the total freshwater to the bay. Five stations (Figure 1) were chosen to represent the range of salinity and environmental conditions encountered along the estuarine gradient, from nearly freshwater (oligohaline; CB1, CT1) to mesohaline (CB2, CT2) to polyhaline (CB3).

\section{COLLECTION AND $\mathbf{N}_{\mathbf{2}}$-FLUX ANALYSIS OF INTACT SEDIMENT CORES}

Sediments were collected from upper (CT1) and lower Choptank River (CT2) stations, as well as mainstem Chesapeake Bay stations (CB1, CB2, CB3; Figure 1) using a box core sampling device deployed from either a small boat or a research vessel in April 2001 (Francis et al., 2003). Sediment samples collected in July 2000 from the upper Choptank River (CT1) were also analyzed in this study, to provide some basis for comparison with the other stations, because a subsample for molecular analysis from CT1 in April 2001 was not available. As reported previously (Francis et al., 2003), bottom water conditions measured at each sampling site are displayed in Table 1. Bottom water temperature, salinity and dissolved $\mathrm{O}_{2}$ were determined with a Sea-Bird CTD or a YSI 600 sonde equipped with an oxygen electrode. Nutrient concentrations were determined on using an automated analyzer (Parsons et al., 1984) on samples collected from Niskin bottles (CB1, CB2, CB3) or using a diaphragm pump (CT1, CT2).

Benthic $\mathrm{N}_{2}$-fluxes were measured in subcores collected from the box cores as described previously (Kana et al., 2006). For each site, three subcores in $6.35 \mathrm{~cm}$ i.d. acrylic core liners $(\sim 15 \mathrm{~cm}$ of sediment and $15 \mathrm{~cm}$ of overlying water) were submersed in an incubator bath of oxic bottom water from the core sampling

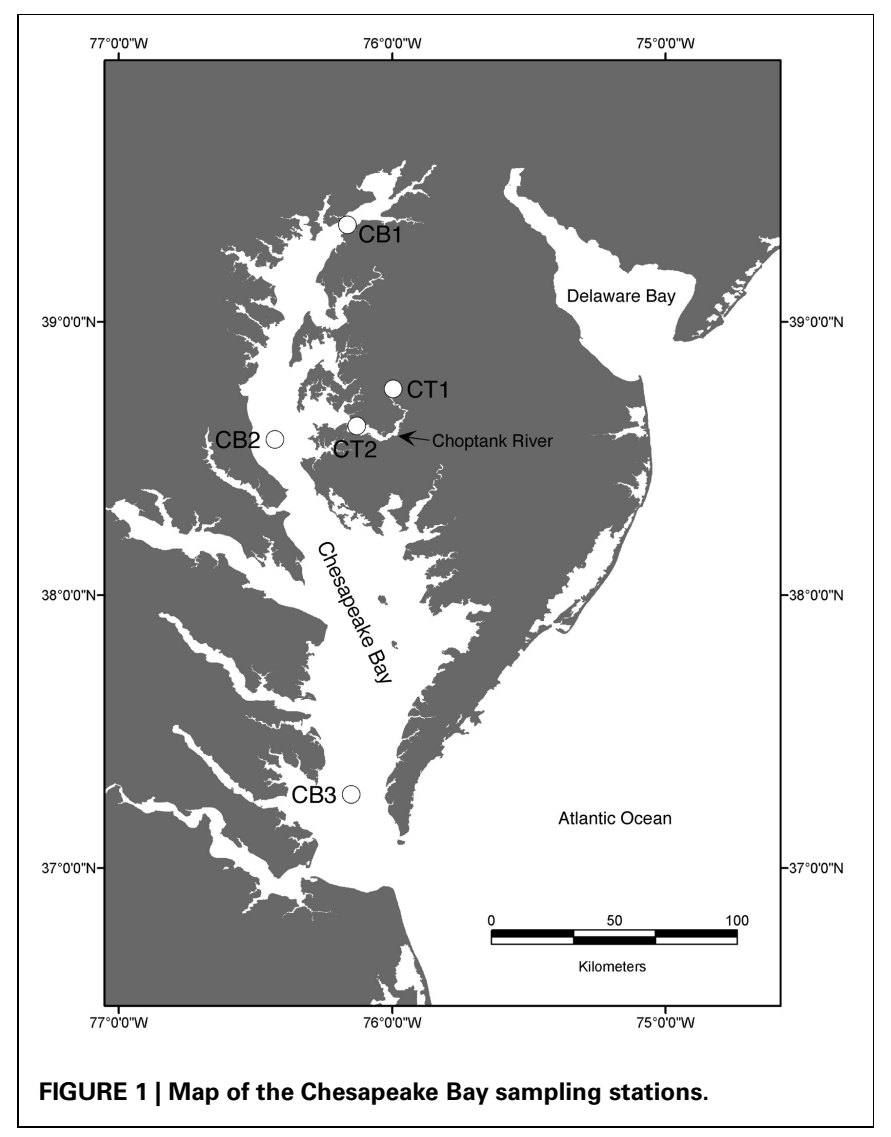


Table 1 | Bottom water environmental parameters and $\mathbf{N}_{\mathbf{2}}$-flux rates for Chesapeake Bay samples analyzed in this study.

\begin{tabular}{lllllllll}
\hline Station & Sampling date & Water depth $(\mathbf{m})$ & $\mathbf{T e m p}\left({ }^{\circ} \mathbf{C}\right)$ & Salinity $(\mathbf{p s u})$ & $\mathbf{N H}_{\mathbf{4}}^{+}(\boldsymbol{\mu} \mathbf{M})$ & $\mathbf{N O}_{\mathbf{3}}^{-}(\boldsymbol{\mu} \mathbf{M})$ & $\mathbf{O}_{\mathbf{2}}(\boldsymbol{\mu} \mathbf{M})$ & $\mathbf{N}_{\mathbf{2}}-\mathbf{N} \mathbf{f l u x}\left(\boldsymbol{\mu} \mathbf{m o l} \mathbf{m}^{-\mathbf{2}} \mathbf{h}-\mathbf{- 1}\right)$ \\
\hline CT1 & July 2000 & 5.5 & 27 & 0.3 & 5 & 44 & NA & 0 \\
CT1 & April 2001 & 5.5 & 7 & 0.0 & 11 & 188 & NA & $149 \pm 51$ \\
CT2 & April 2001 & 7 & 8 & 14.5 & 7 & 22 & NA & $101 \pm 13$ \\
CB1 & April 2001 & 10 & 6.7 & 4.4 & 10 & 83 & 278 & $172 \pm 6$ \\
CB2 & April 2001 & 17.5 & 7.2 & 18.7 & 7 & 22 & 247 & $20 \pm 24$ \\
CB3 & April 2001 & 11 & 8.7 & 23.6 & 4 & 3 & 306 & $8 \pm 13$ \\
\hline
\end{tabular}

NA, Not available.

site, and held overnight with continual aeration and circulation of the overlying water with bath water. Sediment cores and a wateronly control core were capped with O-ring fitted stirring tops and incubated in the dark at in situ $\left( \pm 2^{\circ} \mathrm{C}\right)$ temperatures (see Table 1). When samples were withdrawn at various times during the incubation, replacement bottom water was supplied through a port in the stirring top, using gravity head pressure to fill vials and syringes. Solute samples were filtered using $25 \mathrm{~mm}$ diameter, $0.45 \mu \mathrm{m}$ cellulose acetate syringe filters. Water for dissolved gas analysis was collected in $\sim 7 \mathrm{ml}$ ground glass test tubes that were filled through a small tube placed in the bottom of the vial to minimize gas exchange. Samples were preserved with $10 \mathrm{ml}$ $50 \%$ saturated $\mathrm{HgCl}_{2}$ and stored at near ambient bottom water temperature until analysis.

Incubations were sampled for solutes and gases four times over a time course of $4-8 \mathrm{~h}$, depending on the degree of oxygen depletion. Oxygen concentrations were occasionally monitored using an oxygen electrode early in the incubation, to determine incubation time intervals such that oxygen did not fall below $50 \%$ of air saturation by the final time point.

A quadrupole mass spectrometer with a silicone membrane inlet (Kana et al., 1994, 1998) was used for the analysis of $\mathrm{N}_{2}$ and $\mathrm{O}_{2}$ in flux samples. The $\mathrm{N}_{2}$ :Ar ratios were corrected for any changes due to decreasing $\mathrm{O}_{2}$ concentrations (Kana and Weiss, 2004). Nitrate was analyzed via segmented flow analysis after Cd reduction, and ammonium was manually analyzed using the phenol hypochlorite colorimetric method (Parsons et al., 1984). Benthic $\mathrm{N}_{2}$ fluxes were calculated from the linear regression of the rate of change of $\mathrm{N}_{2}$ concentrations. At the end of the flux measurements, the cores were subsampled using cut-off 5-cc syringes. The sediment was frozen immediately in liquid nitrogen and stored on dry ice or at $-80^{\circ} \mathrm{C}$ until DNA extraction.

\section{Pcr AMPLIFICATION AND CLONING OF nirs GENE FRAGMENTS}

DNA was extracted from replicate $\sim 0.25 \mathrm{~g}$ sediment subsamples $(0-0.5 \mathrm{~cm}$ depth interval) using the FastDNA SPIN kit for soil (MP Biomedicals), as described in Francis et al. (2003). nirS gene fragments ( $\sim 840-890 \mathrm{bp}$ ) were amplified from pooled sediment DNA extracts using the PCR primers (nirS1F and nirS6R) and conditions described by Braker et al. (1998). Products were visualized by electrophoresis in $1.2 \%$ agarose gels stained with ethidium bromide. Triplicate PCR reactions were pooled, gelpurified using the QIAquick gel extraction kit (Qiagen), and cloned into the pCR2.1 vector using the TOPO-TA cloning kit
(Invitrogen). Insert-containing transformants were transferred to 96-well plates containing LB broth (with $50 \mu \mathrm{g} / \mathrm{ml}$ kanamycin) and grown overnight at $37^{\circ} \mathrm{C}$. Clones were screened directly for the presence of inserts by PCR using T7 and M13R vector primers. Sediment DNA extracts were also screened multiple times using two different nirK primer sets, nirK1F/nirK5R (Braker et al., 1998) as well as Cunir3/Cunir4 (Casciotti and Ward, 2001), but no consistent amplification was observed (except for the positive control DNA templates).

\section{SEOUENCING, RICHNESS AND PHYLOGENETIC ANALYSIS OF nirS SEOUENCES}

Sequencing of both strands of T7/M13 PCR products was performed using $\mathrm{ABI} 310$ and 3100 capillary sequencers (PE Applied Biosystems). Nucleotide sequences were assembled, edited, and aligned using Sequencher ${ }^{\mathrm{TM}}$ V.4.2 (GeneCodes Corp.), and translated using MacClade (Maddison and Maddison, 2003). Two different types of phylogenetic analysis were performed, based on nucleotide and amino acid alignments, respectively. The nirS nucleotide alignment (of 550 sequences) was used to define operational taxonomic units (OTUs) on the basis of DNA sequence identity. Distance matrices based on this nucleotide alignment were generated using the PAUP software package. To compare the relative nirS richness within each clone library, rarefaction analysis was performed. For this analysis, OTUs were defined as nirS sequence groups in which sequences differed by $\leq 5 \%$ using the furthest neighbor method in the MOTHUR program (Schloss et al., 2009).

Deduced amino acid sequences of 550 nirS PCR products (after removal of the primer sequences) from the Chesapeake Bay were aligned with representative database sequences (as of July 2012) using ClustalX (Thompson et al., 1997), edited in MacClade, and subjected to phylogenetic analysis. A total of 280 amino acid positions were used in the phylogenetic analysis (shorter database sequences were not included). Neighborjoining and parsimony trees were constructed based on amino acid alignments using the PAUP software package. Bootstrap analysis was used to estimate the reliability of phylogenetic reconstructions (1000 replicates).

\section{STATISTICAL ANALYSES}

Correlation analysis of environmental variables (e.g., $\mathrm{NH}_{4}^{+}, \mathrm{NO}_{3}^{-}$, and salinity) was performed in JMP (SAS Institute, 2002). Extrapolated richness [Abundance-based Coverage Estimators (ACE) and Chaol] and classical diversity (Shannon and 
Simpson's index) estimates were computed using MOTHUR (Schloss et al., 2009). PC-ORD software version 4.01 (McCune and Medford, 1999) was used for multivariate analyses of OTU and environmental data. OTU data were normalized for each site by dividing the number of clones per OTU by the total number of clones sequenced from the site. Environmental data were normalized by dividing the value for each variable at each site by the maximum observed value across sites. Cluster analyses (McCune and Grace, 2002), based on Sorenson distances, were performed for both OTU and environmental matrices. A Mantel Test (Smouse et al., 1986) was used to compare the significance of the observed cluster structure to the structure determined from 1000 randomizations of the matrices.

\section{NUCLEOTIDE SEQUENCE ACCESSION NUMBERS}

The GenBank accession numbers of the nirS sequences from cultivated denitrifiers and environmental clones used for comparison are displayed in Figure 2. The 550 nirS sequences reported in this study have been deposited in GenBank under accession numbers DQ675693 to DQ676242.

\section{RESULTS AND DISCUSSION \\ ENVIRONMENTAL GRADIENTS ALONG THE ESTUARY}

The five Chesapeake Bay stations have been described previously in general terms (Francis et al., 2003) and the specific bottom water conditions at the time of sampling for this study are detailed in Table 1. Along the longitudinal transect from the North Bay (CB1) to South Bay (CB3) station in April 2001 (Figure 1), the salinity increased from 4.4 to 23.6 psu (Table 1 ). While $\mathrm{NH}_{4}^{+}$concentration decreased gradually from 10 to $4 \mu \mathrm{M}$, concentrations of $\mathrm{NO}_{3}^{-}$- the primary electron acceptor for denitrification and generally an indicator of agricultural or urban runoff in estuarine systems - exhibited a much steeper gradient along this same transect, decreasing from 83 to $3 \mu \mathrm{M}$. Similar opposing gradients of salinity and inorganic nitrogen were observed from the oligohaline upper station of the Choptank River (CT1) to the mesohaline lower Choptank station (CT2) (Table 1). The overall physical/chemical conditions at the two mesohaline stations, CT2 and CB2, were quite similar, with identical levels of $\mathrm{NO}_{3}^{-}$ and $\mathrm{NH}_{4}^{+}$and salinities of 14.5 and 18.7 respectively. Key differences between the environmental conditions at CT1 in July 2000 and April 2001 were temperature $\left(27^{\circ} \mathrm{C}\right.$ and $7^{\circ} \mathrm{C}$, respectively) and $\mathrm{NO}_{3}^{-}$concentration $(44 \mu \mathrm{M}$ and $188 \mu \mathrm{M}$, respectively). Oxic conditions were present in the bottom waters of all stations at the time of sediment sampling. Nitrate concentration and salinity were negatively correlated (Spearman $\rho=$ $-0.93 ; p=0.008)$. Cluster analysis of the sites based on normalized values of salinity, nitrate, and ammonium resulted in the formation of two distinct groups (Figure 3). The first group was comprised of $\mathrm{CB} 1$ and $\mathrm{CT} 1$ and the second group comprised of $\mathrm{CB} 2, \mathrm{CT} 2$, and $\mathrm{CB} 3$. The two most similar sites were $\mathrm{CB} 2$ and $\mathrm{CT} 2$.

\section{BENTHIC $\mathrm{N}_{\mathbf{2}}$ FLUXES}

The $\mathrm{N}_{2}$-fluxes measured in sediment cores collected from five stations in April 2001 were negatively correlated to salinity
(Spearman $\rho=-0.90 ; p=0.037$ ), ranging from a high of $172 \mu \mathrm{mol} \mathrm{N} \mathrm{m} \mathrm{m}^{-1}$ at CB1 to a low of $8 \mu \mathrm{mol} \mathrm{N} \mathrm{m} \mathrm{m}^{-2} \mathrm{~h}^{-1}$ at CB3 (Table 1). Although this trend also generally paralleled the nitrate gradient along the Bay, the benthic $\mathrm{N}_{2}$-fluxes at the two mesohaline sites were quite different (CT2 rates were 5 -fold greater than at CB2), despite identical $(22 \mu \mathrm{M})$ bottom water nitrate concentrations. This difference could be due to greater coupling to nitrification at CT2, where the sediments do not experience seasonal anoxia. In contrast, the sediments at the much deeper CB2 station (18-m vs. 7-m depth at CT2) are exposed to seasonally anoxic conditions and have higher levels of pore water hydrogen sulfide (Cornwell and Sampou, 1995), which can inhibit both nitrification and denitrification (Joye and Hollibaugh, 1995). Interestingly, benthic $\mathrm{N}_{2}$-fluxes were undetectable at the upper Choptank River station, CT1, during July 2000, but were quite high in April 2001 (Table 1). These spatial differences, plus seasonal differences illustrated by a wide range of rates at a single site (CT1), highlight the extensive variability often associated with microbial nitrogen transformations in estuarine systems (Cowan and Boynton, 1996; Boynton and Kemp, 2008). The benthic $\mathrm{N}_{2}$ fluxes reported here represent the sum of both conventional denitrification and anammox. However, anammox has been shown to account for only $10-20 \%$ of the total benthic $\mathrm{N}_{2}$ flux at stations CB1, CT1, and CT2, (Rich et al., 2008), and was undetectable at the low-nitrate station CB3. These findings are consistent with previous studies of anammox in other estuarine systems (Risgaard-Petersen et al., 2004; Trimmer et al., 2005), and suggest that denitrification is the dominant N-removal process within Chesapeake Bay sediments.

\section{ANALYSIS OF nirS RICHNESS IN CHESAPEAKE BAY SEDIMENTS}

PCR amplification of nirS gene fragments was obtained from sediment DNA extracts from all five stations. Clone libraries were subsequently generated for each station, and 96 to 123 clones per library were completely sequenced $(\sim 840-890 \mathrm{bp})$, resulting in an overall database of 550 nirS sequences from the Chesapeake Bay estuary. This represents the most extensive clone library-based sequencing effort, to date, of nirS sequences from any system, let alone an estuary. Since nirK could not be reliably amplified (i.e., PCR results ranged from faint, non-specific, or multiple bands to no amplification) from all five of these sediment DNA extracts using several primer combinations (Braker et al., 1998; Casciotti and Ward, 2001), and nirK has been shown to be far less abundant than nirS in other estuarine systems (Abell et al., 2010; Mosier and Francis, 2010), we focused our efforts here on nirS diversity.

To compare the relative nirS-based denitrifier richness between stations, rarefaction analysis was performed on the nirS sequences from using a 5\% cutoff at the DNA level to define an OTU (Figure 4). Rarefaction analysis indicated the greatest nirS richness in the low-salinity upper Choptank River (CT1) and North Bay (CB1) libraries, and the lack of significant curvature after $>95$ clones suggests that that the diversity of distinct nirS sequences is not yet saturated in these two libraries. By far the lowest richness was observed in the South Bay (CB3) library, while intermediate levels were observed at the two mesohaline stations, CT2 and CB2. Overall, the rarefaction curves illustrate a rather striking 


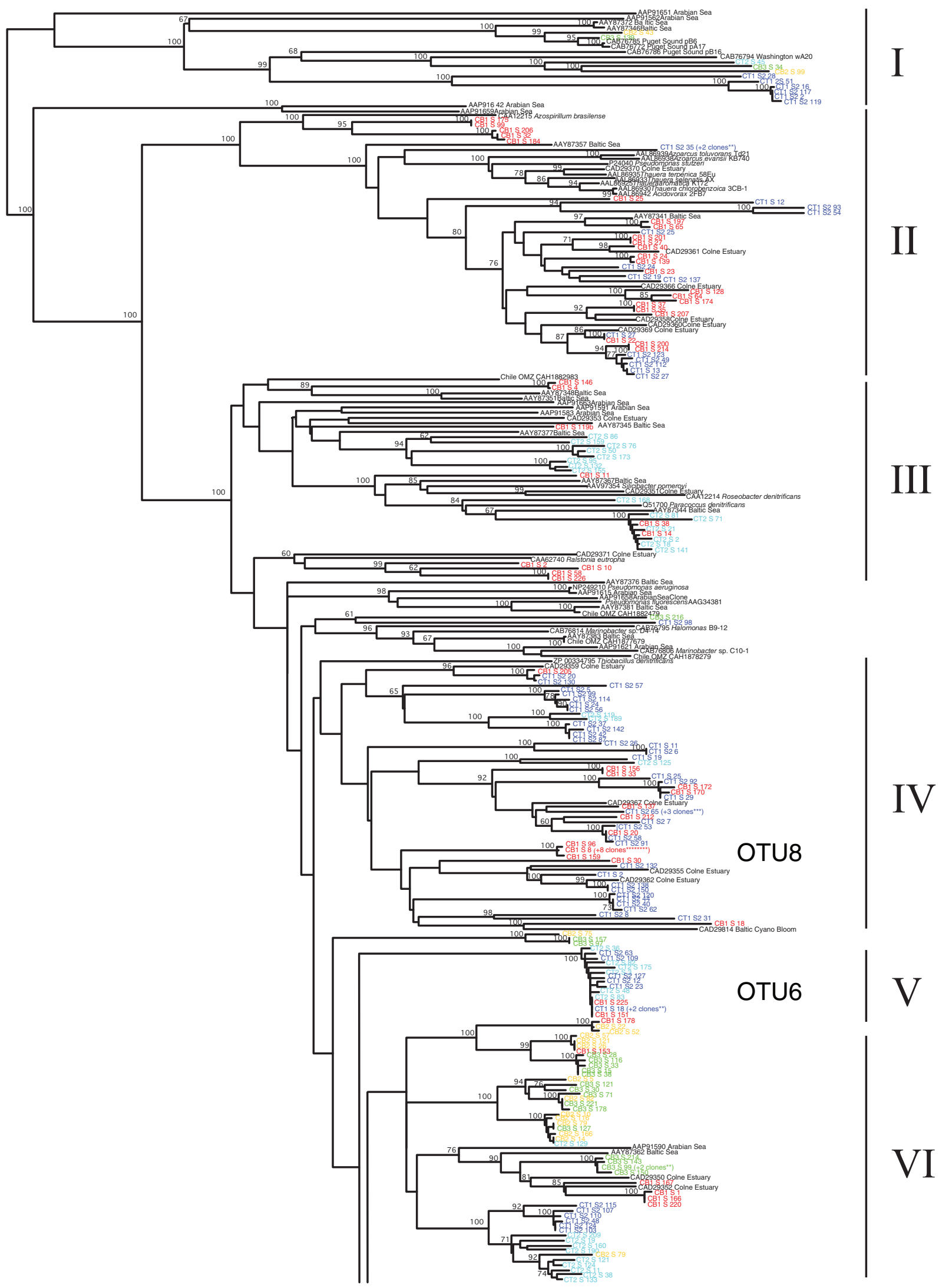

FIGURE 2 | Continued 


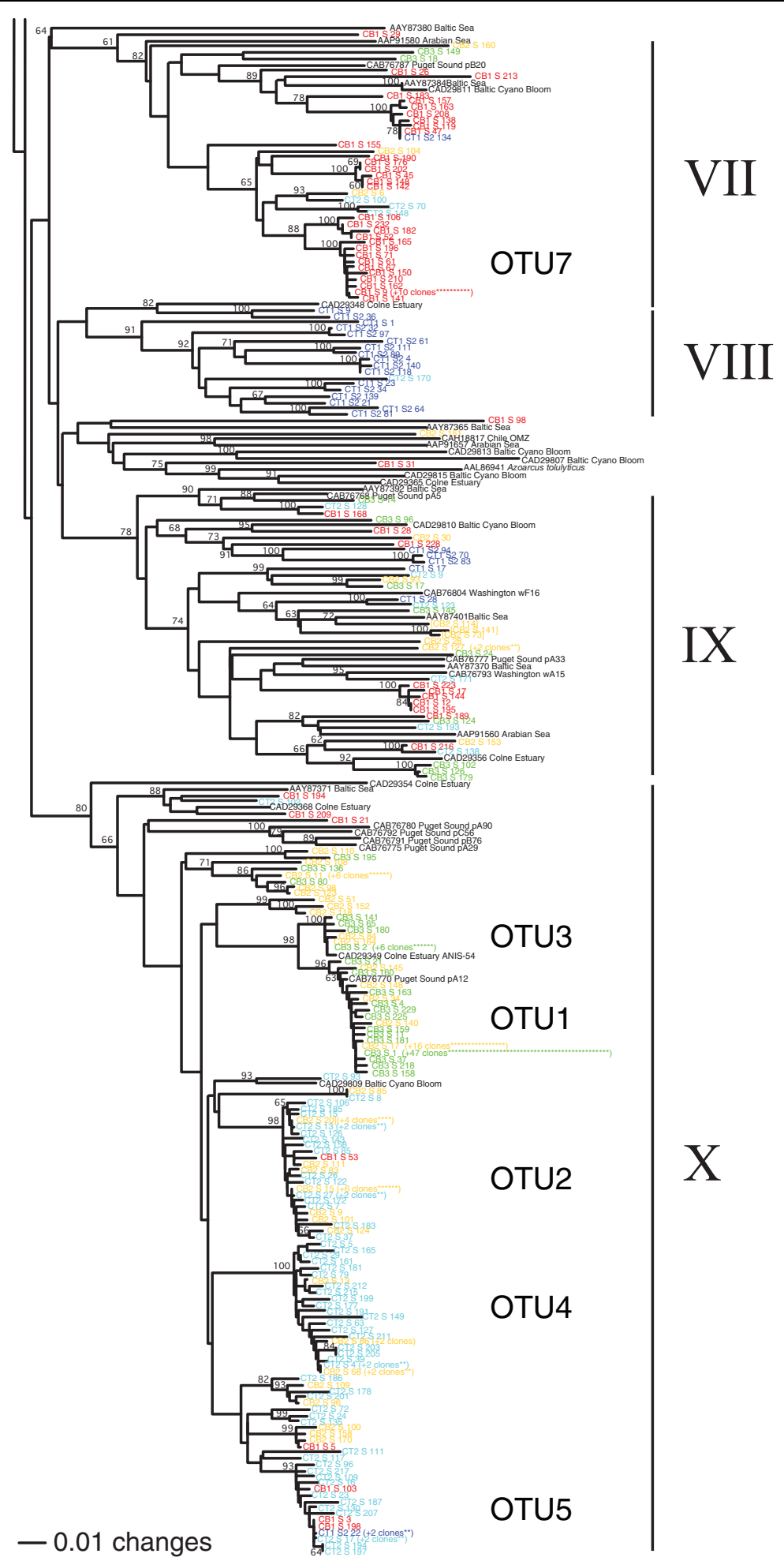

FIGURE 2 | Neighbor-joining phylogenetic tree of deduced NirS amino acid sequences (280 positions considered) from Chesapeake Bay sediments. Bootstrap values $(\geq 60 \%)$ are shown at the branch points. Sequences from the present study are shown in color by station (CB1, red; CB2, yellow; CB3, green; CT1, blue; CT2, aqua) Database sequences are shown in black along with the corresponding GenBank accession numbers. The number of clones identical at the amino acid level is indicated in parentheses (only for those sequences occurring $>2$ times within a clone library). Roman numerals refer to the ten clusters discussed in the text, all of which were also present in the parsimony tree (not shown). Clusters of NirS sequences corresponding to the 8 major nucleotide-based OTUs (defined according to $5 \%$ nucleotide sequence difference using the farthest neighbor method) are also indicated. 
trend among these sites spanning the estuarine salinity gradient, in which nirS richness decreased as salinity increased along the estuary (Figure 4 and Table 2). This trend is consistent with a previous study reporting that nirS diversity was inversely correlated with salinity in a wastewater treatment plant (Yoshie et al., 2004).

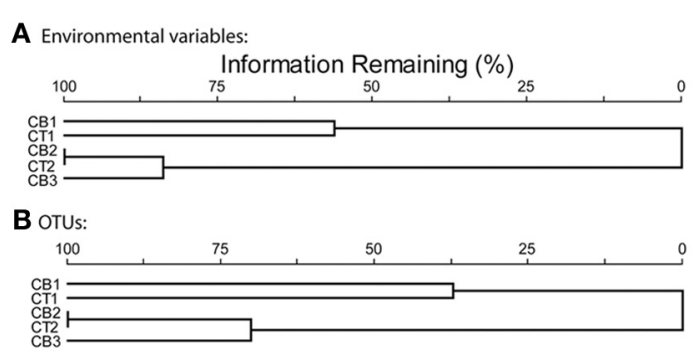

FIGURE 3 | Cluster analyses of five Chesapeake Bay sites based on relativized data using Sorenson distances. (A) ammonium, nitrate and salinity data, (B) OTU distribution data, defined according to $5 \%$ nucleotide sequence difference using the farthest neighbor method.

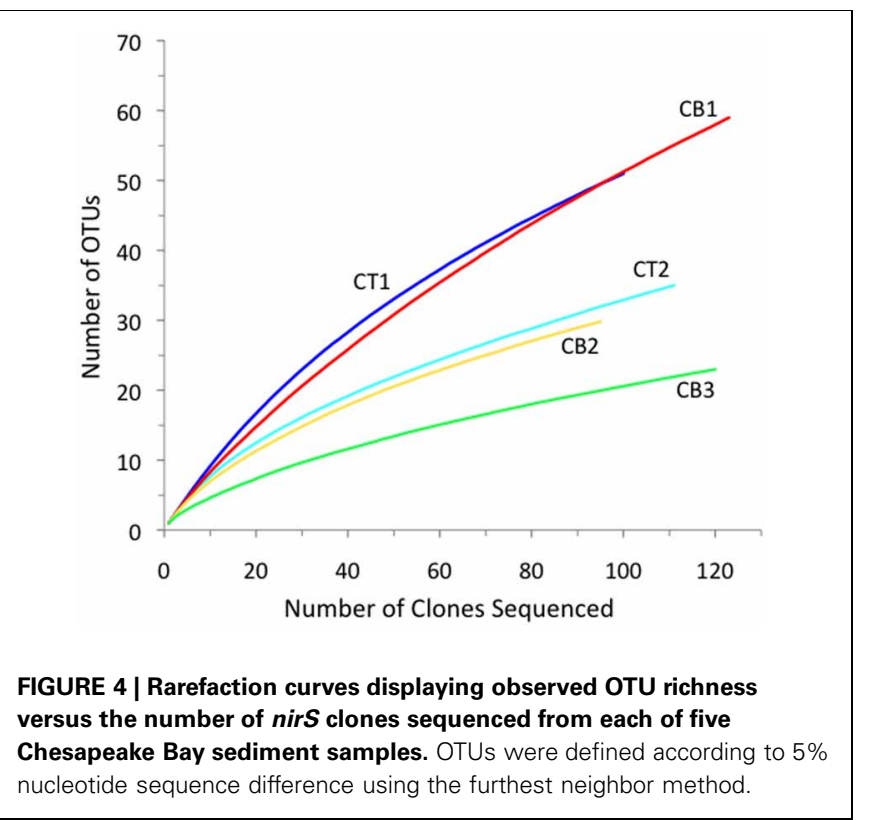

Interestingly, no clear trends in nirS richness across estuarine salinity gradients were observed in Huntington Beach (Santoro et al., 2006) or San Francisco Bay (SFB; Mosier and Francis, 2010); however, both nirS abundance and denitrification potential activity were correlated with salinity in SFB, further highlighting the significance of this environmental factor in large North American estuaries.

The freshwater/oligohaline stations (CT1 and CB1) had the greatest total number of OTUs that were found exclusively at one site (Table 2). Interestingly, using the same OTU definition ( $5 \%$ cutoff), betaproteobacterial amoA richness was also greatest in the North Bay (CB1) but the lowest and essentially identical levels of richness were detected at the two mesohaline stations, CT2 and CB2, and intermediate levels at CT1 and CB3 (Francis et al., 2003). Thus, the relative richness/diversity of denitrifying and $\mathrm{AO}$ communities (based on functional genes) may be influenced differently by physical/chemical parameters, such as salinity and oxygen. It is clear that salinity has a direct, if imperfectly understood, effect on ammonia oxidizer diversity and activity (De Bie et al., 2001; Caffrey et al., 2003; Francis et al., 2003; Bernhard et al., 2005, 2007; Ward et al., 2007; Mosier and Francis, 2008); however, it is worth noting that some studies have found other factors (e.g., $\mathrm{pH}$ ) to be important in structuring estuarine $\mathrm{AO}$ communities (Dang et al., 2010). Nitrate, which covaries with salinity in this system, and organic matter flux may be more important for denitrifiers. Given the limited number of samples (5) in this study, we are not able to untangle the potentially complex influence of these factors with our data; nevertheless, the pattern of changing nirS diversity along the salinity gradient is striking.

Although rarefaction analysis is useful for comparing the relative observed richness among clone libraries, it is not intended to predict the actual community richness (i.e., total number of OTUs) within the original samples (Hughes et al., 2001). Therefore, we also utilized several non-parametric richness estimators and diversity indices to analyze the nirS clone library data (Table 2). The extrapolated richness estimates (Chaol and ACE) were generally much higher ( $\sim 2-3$-fold) than the observed richness within a given library. For example, the total number of observed nirS OTUs within our dataset (172 OTUs) represented only 37 to $48 \%$ of the number of OTUs predicted by ACE and Chaol, respectively. Overall, the predicted nirS richness values basically exhibited the same trend from high to low richness

Table 2 | Richness and diversity statistics for nirS clone libraries from five Chesapeake Bay sediment samples.

\begin{tabular}{|c|c|c|c|c|c|c|c|}
\hline Station & No. of clones & No. of OTUs & Unique OTUs* & $\mathrm{ACE}^{\dagger}$ & Chao1 $^{\dagger}$ & Shannon & Simpson's \\
\hline $\mathrm{CT} 1$ & 100 & 51 & 44 & 97 & 95 & 3.69 & 0.02 \\
\hline $\mathrm{CT} 2$ & 111 & 35 & 25 & 126 & 88 & 2.98 & 0.07 \\
\hline CB2 & 96 & 30 & 18 & 82 & 57 & 2.75 & 0.10 \\
\hline CB3 & 120 & 23 & 17 & 80 & 46 & 1.79 & 0.35 \\
\hline
\end{tabular}

${ }^{\dagger}$ ACE and Chao1 are non-parametric estimators which predict the total number of OTUs in the original sample.

* OTUs detected in only 1 of the 5 Chesapeake Bay sediment samples. 
along the estuarine gradient that was revealed through rarefaction analysis. The classical ecological diversity indices (Shannon and Simpson's) also supported this trend.

\section{ANALYSIS OF OTU DISTRIBUTIONS}

The number of OTUs shared between sites represents one measure of site similarity (Table 3). CT1 and CB1 had the greatest number of site-specific OTUs, while CB2 and CB3 had the greatest degree of overlap in OTU occurrence. A second measure of site similarity is the frequency of shared OTUs among sites. OTUs representing a large portion of the sequenced clones (i.e., the most abundant sequences within the clone libraries) have a large impact on this second measure of site similarity. Eight of the 172 nirS OTUs detected in the Chesapeake Bay accounted for 232 $(42 \%)$ of the total sequences (Figure 5). Of these eight abundant OTUs, only two were unique to a particular site (OTUs 7 and 8 from $\mathrm{CB} 1$ ), while the remaining six each included sequences from two or more sites, as well as sequences from a mesohaline site. All 8 major OTUs corresponded to distinct phylogenetic clusters in the NirS amino acid tree in Figure 2. OTU1 contained the greatest number of sequences, including 71 CB3 and 20 CB2 sequences (Figure 5). The other 164 OTUs were mostly rare, 101 of which were represented by only a single nirS sequence (i.e., singletons).

In order to quantify the distribution of OTUs across sites, including information from both the number of shared OTUs and the relative frequency of OTUs, a cluster analysis based on normalized OTU distribution was performed. This analysis revealed the same two station groups that had been identified in the cluster analysis of environmental data above (Figure 3). The first group was comprised of CB1 and CT1 and the second group contained CB2, CT2, and CB3 (Figure 3). The mesohaline sites, CB2 and CT2, were most similar in terms of both OTUs and environmental characteristics. A Mantel test indicated that the correspondence of OTU distribution and environmental variables was significant $(p=0.006)$. The observed clustering of environmental variables and sampling sites suggests a relationship between environmental factors and OTU distribution. However, the rather limited number of samples (5) ultimately limits our statistical power to definitively determine the impact of particular factors on the distribution of nirS-type denitrifier populations. While it is not always feasible (or desirable) to generate massive PCR clone libraries for the extensive number of samples necessary to perform more robust statistical approaches (e.g., non-metric multidimensional scaling), the extensive nirS dataset described in

Table 3 | Shared nirS OTUs from five Chesapeake Bay sediment samples.

\begin{tabular}{llllll}
\hline \multirow{2}{*}{ Station } & \multicolumn{5}{c}{ No. of } \\
\cline { 2 - 6 } & CT1 & CT2 & CB1 & CB2 & CB3 \\
\hline CT1 & - & 2 & 7 & 0 & 0 \\
CT2 & & - & 6 & 5 & 1 \\
CB1 & & & - & 4 & 0 \\
CB2 & & & & - & 6 \\
CB3 & & & & & - \\
\hline
\end{tabular}

this study allowed the development of a microarray (Bulow et al., 2008) that can now be used to easily screen a much larger number of samples (e.g., Jayakumar et al., in press).

\section{PHYLOGENETIC ANALYSIS OF CHESAPEAKE BAY nirS SEQUENCES}

In addition to comparing the relative richness and OTU distribution of nirS sequences, we examined the phylogenetic relationships of these sequences (Figure 2). The deduced amino acid sequences of the 550 nirs clones from Chesapeake Bay sediments showed only $35-85 \%$ identity to sequences of cultivated denitrifying strains. Instead, the majority of the sequences fell into phylogenetic clusters comprised primarily of Chesapeake Bay sequences and, in some cases, closely related marine and estuarine environmental clones (Figure 2).

For the purposes of this discussion, we have grouped the sequences into 10 broadly defined clusters/regions of the tree. As suggested by the extensive richness of nirS OTUs associated with the two oligohaline stations, CT1 and CB1, the sequences from these sites were distributed among numerous branches throughout the tree (Figure 2). However, even the less abundant sequences and OTUs exhibited substantial overlap between CB1 and CT1, as might be expected from the similarity in physical/chemical characteristics of CB1 and CT1. In fact, many sequences from these stations fell into similar regions or clusters of the phylogenetic tree, including two large clusters (II and IV) in the upper region of the tree (Figure 2) comprised almost exclusively of CT1 and CB1 sequences. Interestingly, all but one of the mRNA nirS clones recovered from the low-salinity, hyper-nutrified ( $1 \mathrm{mM}$ nitrate) Hythe site, located at the head of the River Colne estuary (Nogales et al., 2002), also fell into these clusters, several of which were $>95 \%$ identical to these Chesapeake sequences. The similar salinity regimes at these two geographically-distinct upper estuarine sites, despite considerably higher nitrate concentrations in the Colne estuary, support the importance of salinity (or an environmental factor that co-varies

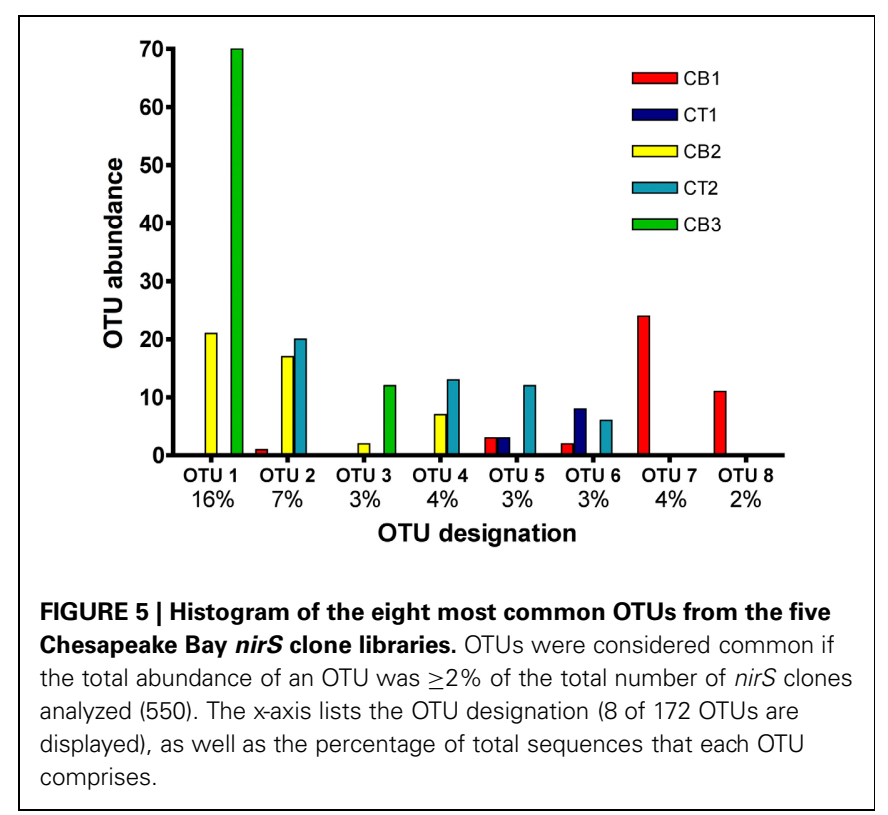


with salinity) as a key determinant in structuring denitrifying communities. Furthermore, the nirS sequences in Clusters II and IV apparently correspond to "low-salinity" groups of estuarine denitrifiers.

In addition to the "low-salinity" sequence types, the remaining CT1 and CB1 sequences were dispersed throughout the tree, either in discrete site-specific clusters or within clusters of sequences from other CB sites, possibly corresponding to denitrifiers that have a wide salinity tolerance. In addition to those CT1 and CB1 sequences that fell broadly into similar clusters, $13-19 \%$ of the sequences in each library were essentially identical (>99\% amino acid identity) to sequences from the other site. In the absence of clone library analysis from CT1 in April 2001, comparisons between $\mathrm{CB} 1$ and CT1 unavoidably combine temporal and spatial variation. Even less overlap was observed in the amoA sequence types recovered from these two sites (Francis et al., 2003), perhaps reflecting differences in how salinity influences the composition of $\mathrm{AO}$ and denitrifying communities. Despite similar conditions, these upper bay and river sites experience quite different allochthonous inputs (urban vs. agricultural, respectively), which likely include microbes as well as nutrients, and these factors may interact with the physiological response to salinity.

While only three CT2 sequences fell into the two "low-salinity" clusters (II and IV), more than half (59 of 111 sequences) of the CT2 sequences fell into three distinct but closely related subclusters within cluster $\mathrm{X}$ (corresponding largely to OTU2, 4, and 5 from Figure 5). Cluster X contains a small number of CT1 and $\mathrm{CB} 1$ sequences, but is clearly dominated by sequences from mesohaline and polyhaline sites. Interestingly, there was considerable overlap between sequences from CT2 and CB2, as well as CB2 and CB3, but virtually no overlap between CT2 and CB3 (Figure 2) (also demonstrated in Figure 5 and Table 3).

The mesohaline CB2 station represents the transition zone between the North and South Bay sites, as well as the junction between the mainstem of the Bay and the Choptank River. Like the transition from CT1 to CT2, a shift in both denitrifier richness (Figure 4 and Table 2) and community composition (Figure 2) occurred between CB1 and CB2. Although the "true" (e.g., 16S rRNA-based) phylogenetic affiliations of denitrifiers cannot usually be determined based on nirS functional gene sequences alone, it is tempting to speculate that the shift in nirS sequence types from $\mathrm{CB} 1$ to $\mathrm{CB} 2$ in part reflects a major overall compositional shift in the sedimentary microbial communities between the oligohaline stations and mesohaline stations. Indeed, the transition from oligohaline to mesohaline conditions in estuarine systems is often accompanied by dramatic shifts in microbial community structure (De Bie et al., 2001), and the Chesapeake Bay estuary is no exception. Using $16 \mathrm{~S}$ rRNA probes to enumerate the main groups of Proteobacteria by fluorescence in situ hybridization (FISH), Bouvier and del Giorgio (2002) found consistent community shifts between the upper and lower Choptank River (CT) regions. Betaproteobacteria were abundant in the freshwater stations, but were rare in the lower river and the opposite pattern was observed for Alphaproteobacteria. The switch occurred at approximately the location of our station CT2, suggesting that a shift in the community structure of proteobacterial denitrifiers might also be expected between the two river stations, CT1 and CT2 (Taroncher-Oldenburg et al., 2003), and possibly $\mathrm{CB} 1$ and CB2.

Perhaps the most striking feature of the phylogenetic tree (Figure 2) is the large cluster of 83 closely-related CB3 sequences (and 23 CB2 sequences) within cluster X (corresponding to OTU1 and OTU3 in Figure 5), which share $95-100 \%$ amino acid identity to sequences of RT-PCR and PCR clones recovered from meso- to poly-haline sites within the River Colne estuary (Nogales et al., 2002) and Puget Sound (Braker et al., 2000), respectively. Within the OTU1 subcluster, 47 CB3 clones (represented by CB3S-1) and 17 CB2 clones (represented by CB2-S-17) were 100\% identical. Interestingly, these sequences also shared $>99 \%$ identity with mRNA clones obtained from Narragansett Bay sediment mesocosms (Fulweiler et al., 2013). The remarkable similarity between these dominant mid- and South Chesapeake Bay sequences and sequences from multiple geographically-distinct estuaries suggests that these nirS genotypes may be ubiquitous in mesohaline to polyhaline (15-30 psu) sedimentary environments. Furthermore, using a nirS microarray, developed using sequences from this study, Bulow et al. (2008) demonstrated that sequences corresponding to the dominant CB3 nirS genotypes (OTU1) as well as the major CT2/CB2 sequence type (OTU2) within Cluster $\mathrm{X}$ were the most abundant (DNA) and most actively expressed (mRNA) within both CB2 and CB3 sediments. It is worth highlighting that 5 of the 8 most abundant nucleotide-based OTUs identified in the present study (Figure 5) correspond to welldefined clusters of NirS amino acid sequences within Cluster X (Figure 2), all of which are distinct from known cultivated denitrifiers. The microarray format used by Bulow et al. (2008) is capable of distinguishing nirS sequences that differ by $13-15 \%$ sequence identity (Taroncher-Oldenburg et al., 2003). Thus it is likely that 70-mer probes based on OTU1 and OTU2 sequences (defined based on a $5 \%$ identity cutoff) would collectively detect sequences corresponding to all 5 major OTUs within Cluster $\mathrm{X}$. The microarray results verify that not only are these Cluster $\mathrm{X}$ sequences most abundant in Chesapeake Bay, but they also represent the most active groups.

Although the vast majority of sequences from the Chesapeake Bay were either site-specific or clustered with sequences from sites with similar physical/chemical characteristics, $5-10 \%$ of the cloned sequences from all five sites fell into one large wellsupported phylogenetic cluster (IX). This cluster also included 10 clones from a number of different environments, including sediments from the River Colne estuary, Puget Sound, and Washington continental margin, as well as water column depths within the Baltic Sea and the coastal Arabian Sea oxygen minimum zone. The only cultivated member of this cluster is Azoarcus tolulyticus, a nitrogen-fixing betaproteobacterium that can degrade toluene under denitrifying conditions (Zhou et al., 1995; Song and Ward, 2002). This cluster is thus not only widely distributed geographically, but also among several different kinds of estuarine and marine environments.

The most divergent nitrite reductase sequences obtained in this study, sharing only $35-40 \%$ amino acid identity with the nearest cultivated denitrifier sequence, fell into Cluster I along with related sequences from several other marine and 
sedimentary environments. These distinct sequences represented $2 \%$ of the total 550 nirS sequences in this study, comprising 6\% of the CT1 clones, and 1-2\% of three other libraries, but were not found in the CB1 library. Although Cluster I sequences are quite distinct from most known NirS sequences, there appears to be conservation of key amino acid residues known to be critical for function. For example, Histidine 352 ( $P$. aeruginosa numbering), which serves as a heme- $d_{1}$ ligand in the active site of cytochrome$c d_{1}$ nitrite reductase enzymes, was conserved among Cluster I and all other sequences in this study.

\section{CONCLUSIONS}

This study has revealed extensive and unprecedented nirS diversity within Chesapeake Bay estuarine sediments, with the vast majority of 550 sequences falling into numerous novel phylogenetic clusters, lineages, and OTUs, many of which may represent estuarine-specific sequence types. Both the benthic $\mathrm{N}_{2}$ fluxes and nirS gene sequences were non-randomly distributed in relation to the physical/chemical parameters observed across the five estuarine sites. While salinity was most obviously related to the benthic $\mathrm{N}_{2}$ fluxes and observed diversity patterns, covariation of key parameters and the limited number of sampling sites makes it difficult to definitively determine the importance of individual environmental factors in this study. A clear shift in nirS phylogeny and richness occurred between the freshwater and mesohaline stations, where the steepest environmental gradients were also observed. In contrast, the transition from the mesohaline mid-Bay station to the polyhaline South Bay station was less

\section{REFERENCES}

Abell, G. C. J., Revill, A. T., Smith, C., Bissett, A. P., Volkman, J. K., and Robert, S. S. (2010). Archaeal ammonia oxidizers and nirS-type denitrifiers dominate sediment nitrifying and denitrifying populations in a subtropical macrotidal estuary. ISME J. 4, 286-300. doi: 10.1038/ismej.2009.105

Bernhard, A. E., Donn, T., Giblin, A. E., and Stahl, D. A. (2005). Loss of diversity of ammonia-oxidizing bacteria correlates with increasing salinity in an estuary system. Environ. Microbiol. 7, 1289-1297. doi: $\quad$ 10.1111/j.1462-2920.2005. 00808. $\mathrm{x}$

Bernhard, A. E., Tucker, J., Giblin, A. E., and Stahl, D. A. (2007). Functionally distinct communities of ammonia-oxidizing bacteria along an estuarine salinity gradient. Environ. Microbiol. 9, 1439-1447. doi: $\quad 10.1111 /$ j.1462-2920.2007. 01260. $\mathrm{x}$

Bouvier, T. C., and del Giorgio, P. A. (2002). Compositional changes in free-living bacterial communities along a salinity gradient in two temperate estuaries. Limnol. Oceanogr. 47, 453-470. doi: 10.4319/lo.2002. 47.2.0453
Boynton, W. R., and Kemp, M. (2008). "Estuaries," in Nitrogen in the Marine Environment, 2nd Edn., eds D. G. Capone, D. A. Bronk, M. R. Mullholland, and E. J. Carpenter (New York, NY: Academic Press), 809-866.

Braker, G., Ayala-del-Rio, H. L., Devol, A. H., Fesefeldt, A., and Tiedje, J. M. (2001). Community structure of denitrifiers, Bacteria, and Archaea along redox gradients in Pacific Northwest marine sediments by terminal restriction fragment length polymorphism analysis of amplified nitrite reductase (nirS) and 16S rRNA genes. Appl. Environ. Microbiol. 67, 1893-1901. doi: 10.1128/AEM.67.4.1893-1901.2001

Braker, G., Fesefeldt, A., and Witzel, K. P. (1998). Development of PCR primer systems for amplification of nitrite reductase genes (nirK and nirS) to detect denitrifying bacteria in environmental samples. Appl. Environ. Microbiol. 64, 3769-3775.

Braker, G., Zhou, J., Wu, L., Devol, A. H., and Tiedje, J. M. (2000). Nitrite reductase genes (nirK and nirS) as functional markers to investigate diversity of denitrifying bacteria in Pacific Northwest marine sediment

pronounced, with considerable overlap observed in nirS sequence types and fairly comparable richness. Sequences were not evenly distributed among the stations, however, and some dominant nirS genotypes (within clone libraries) were identified, especially at CB3, the most "marine" site. The eight most abundant OTUs accounted for $42 \%$ of the total sequences, consistent with the idea that nirS-type denitrifiers exhibit a typical "species" abundance curve, with a few very common types and many rare ones. The dominant nirS genotypes identified here are not obviously affiliated with known denitrifying strains, which implies that we know very little about a group of organisms that are numericallydominant (and active in gene expression) in this system and ubiquitous in estuarine systems in general. Recent advances in high-throughput sequencing technology will undoubtedly allow future studies to more thoroughly survey the diversity of nirS sequences, and microarray technologies will allow a larger number of samples to be investigated so that interactions with complex environmental factors can be better understood. However, further cultivation and/or metagenomic investigations will ultimately be required to determine the phylogenetic and physiological nature of these estuarine denitrifier groups.

\section{ACKNOWLEDGMENTS}

This research was supported in part by an NSF Biocomplexity research grant to Bess B. Ward. (OCE-9981482) and an NSF Postdoctoral Research Fellowship in Microbial Biology to Christopher A. Francis (DBI-0102106). We thank Jeff Alexander, Mike Owens, and Lora Pride for field and laboratory assistance.

communities. Appl. Environ. Microbiol. 66, 2096-2104. doi: 10.1128/AEM.66.5.2096-2104.2000

Bulow, S. E., Francis, C. A., Jackson, G. A., and Ward, B. B. (2008). Sediment denitrifier community composition and nirS gene expression investigated with functional gene microarrays. Environ. Microbiol. 10, 3057-3069. doi: 10.1111/j.1462-2920.2008.01765.x

Caffrey, J. M., Harrington, N., Solem, I., and Ward, B. B. (2003) Biogeochemical processes in a small California estuary. 2. Nitrification activity, community structure and role in nitrogen budgets. Mar. Ecol. Prog. Ser. 248, 27-40. doi: $10.3354 /$ meps 248027

Casciotti, K. L., and Ward, B. B. (2001). Dissimilatory nitrite reductase genes from autotrophic ammoniaoxidizing bacteria. Appl. Environ. Microbiol. 67, 2213-2221. doi: 10.1128/AEM.67.5.2213-2221.2001

Castro-González, M., Braker, G., Farías, L., and Ulloa, O. (2005). Communities of nirS-type denitrifiers in the water column of the oxygen minimum zone in the eastern South Pacific. Environ. Microbiol. 7, 1298-1306. doi: 10.1111/j.1462-2920.2005.00809.x
Christensen, J. P., Smethie W. M. Jr., and Devol, A. H. (1987). Benthic nutrient regeneration and denitrification on the Washington continental shelf. Deep-Sea Res. 34, 1027-1047. doi: 10.1016/0198-0149(87)90051-3

Cornwell, J. C., Kemp, W. M., and Kana, T. M. (1999). Denitrification in coastal ecosystems: methods, environmental controls, and ecosystem level controls, a review. Aquat. Ecol. 33, 41-54. doi: 10.1023/A:10099214 14151

Cornwell, J. C., and Sampou, P. A. (1995). "Environmental controls on iron sulfide mineral formation in a coastal plain estuary," in Geochemical Transformations of Sedimentary Sulfur, eds M. A. Vairavamurthy, and M. A. A. Schoonen (Washington, DC: American Chemical Society), 224-242. doi: 10.1021/bk-19950612.ch012

Cowan, J. L. W., and Boynton, W. R. (1996). Sediment-water oxygen and nutrient exchanges along the longitudinal axis of Chesapeake Bay: seasonal patterns controlling factors and ecological significance. Estuaries 19, 562-580. doi: $10.2307 / 1352518$ 
Dalsgaard, T., Canfield, D. E., Petersen, J., Thamdrup, B., and CunaGonzalez, J. (2003). N2 production by the anammox reaction in the anoxic water column of Golfo Dulce, Costa Rica. Nature 422, 606-608. doi: 10.1038/nature01526

Dang, H., Li, J., Chen, R., Wang, L., Guo, L., Zhang, Z., et al. (2010). Diversity, abundance, and spatial distribution of sediment ammoniaoxidizing betaproteobacteria in response to environmental gradients and coastal eutrophication in Jiaozhou Bay, China. Appl. Environ. Microbiol. 76, 4691-4702. doi: 10.1128/AEM.02563-09

Dang, H. Y., Wang, C. Y., Li, J., Li, T. G., Tian, F., Jin, W., et al. (2009). Diversity and distribution of sediment NirS-encoding bacterial assemblages in response to environmental gradients in the eutrophied Jiaozhou Bay, China. Microb. Ecol. 58, 161-169. doi: 10.1007/s00248008-9469-5

De Bie, M. J., Speksnijder, A. G., Kowalchuk, G. A., Schuurman, T., Zwart, G., Stephen, J. R., et al. (2001). Shifts in the dominant populations of ammonia-oxidizing $B$ subclass Proteobacteria along the eutrophic Shelde estuary. Aquat. Microb. Ecol. 23, 225-236. doi: 10.3354/ame023225

Devol, A. H. (2008). "Denitrification including anammox," in Nitrogen in the Marine Environment, 2nd Edn., eds D. G. Capone, D. A. Bronk, M. R. Mullholland, and E. J. Carpenter (New York, NY: Academic Press), 263-302.

Francis, C. A., Beman, J. M., and Kuypers, M. M. M. (2007). New processes and players in the nitrogen cycle: the microbial ecology of anaerobic and archaeal ammonia oxidation. ISME J. 1, 19-27. doi: 10.1038/ismej.2007.8

Francis, C. A., O'Mullan, G. D., and Ward, B. B. (2003). Diversity of amoA ammonia monooxygenase genes across environmental gradients in Chesapeake Bay sediments. Geobiology 1, 129-140. doi: 10.1046/j.1472-4669.2003.00010.x

Fulweiler, R. W., Brown, S. M., Nixon, S. W., and Jenkins, B. D. (2013). Evidence and a conceptual model for the co-occurrence of nitrogen fixation and denitrification in heterotrophic marine sediments. Mar. Ecol. Prog. Ser. 482, 57-68. doi: 10.3354/meps10240

Hannig, M., Braker, G., Dippner, J., and Jurgens, K. (2006). Linking denitrifier community structure and prevalent biogeochemical parameters in the pelagial of the central
Baltic Proper (Baltic Sea). FEMS Microbiol. Ecol. 57, 260-271. doi: 10.1111/j.1574-6941.2006.00116.x

Hughes, J. B., Hellmann, J. J., Rocketts, T. H., and Bohannan, B. J. M. (2001). Counting the uncountable: statistical approaches to estimating microbial diversity. Appl. Environ. Microbiol. 67, 4399-4406. doi: 10.1128/AEM.67.10.43994406.2001

Jayakumar, D. A., Francis, C. A., Naqvi, S. W. A., and Ward, B. B. (2004). Diversity of nitrite reductase genes (nirS) in the denitrifying water column of the coastal Arabian Sea. Aquat. Microb. Ecol. 34, 69-78. doi: 10.3354/ame 034069

Jayakumar, D. A., Naqvi, S. W. A., and Ward, B. B. (2009). "Distribution and relative quantification of key genes involved in fixed nitrogen loss from the Arabian Sea oxygen minimum zone," in Indian Ocean Biogeochemical Processes and Ecological Variability, eds J. D. Wiggert, and R. R. Hood (Washington, DC: American Geophysical Union), 187-203. doi: 10.1029/2008GM000730

Jayakumar, A., Peng, X., and Ward, B. B. (in press). Community composition of bacteria involved in fixed nitrogen loss in the water column of two major oxygen minimum zones in the ocean. Aqua. Microb. Ecol. doi: 10.3354/ame01654

Jensen, K., Revsbech, N. P., and Nielsen, L. P. (1993). Microscale distribution of nitrification activity in sediment determined with a shielded microsensor for nitrate. Appl. Environ. Microbiol. 59, 3287-3296.

Jensen, K., Sloth, N. P., RisgaardPetersen, N., Rysgaard, S., and Revsbech, N. P. (1994). Estimation of nitrification and denitrification from microprofiles of oxygen and nitrate in model sediment systems. Appl. Environ. Microbiol. 60, 2094-2100.

Joye, S. B., and Hollibaugh, J. T. (1995). Influence of sulfide inhibition of nitrification on nitrogen regeneration in sediments. Science 270, 623-625. doi: 10.1126/science. 270.5236 .623

Kana, T. M., Cornwell, J. C., and Zhong, L. J. (2006). Determination of denitrification in the Chesapeake Bay from measurements of $\mathrm{N} 2$ accumulation in bottom water Estuaries Coasts 29, 222-231. doi: 10.1007/BF02781991

Kana, T. M., Darkangelo, C., Hunt, M. D., Oldham, J. B., Bennett, G. E., and Cornwell, J. C. (1994) Membrane inlet mass spectrometer for rapid high-precision determination of $\mathrm{N}_{2}, \mathrm{O}_{2}$, and $\mathrm{Ar}$ in environmental water samples. Anal. Chem. 66, 4166-4170. doi: 10.1021/ac00095a009

Kana, T. M., Sullivan, M. B., Cornwell, J. C., and Groszkowski, K. (1998). Denitrification in estuarine sediments determined by membrane inlet mass spectrometry. Limnol. Oceanogr. 42, 334-339. doi 10.4319/lo.1998.43.2.0334

Kana, T. M., and Weiss, D. L. (2004) Comment on "Comparison of isotope pairing and N2:ar methods for measuring sediment denitrirification" By, B.D Eyre, S., Rysgaard, and P. Bondo Christensen. 2002. Estuaries 25, 1077-1087." Estuaries 27, 173-176. doi: 10.1007/BF02803571

Kemp, W. M., Sampou, P., Caffrey, J., Mayer, M., Henriksen, K., and Boynton, W. R. (1990). Ammonia recycling versus denitrification in Chesapeake Bay sediments. Limnol. Oceanogr. 35, 1545-1563. doi: 10.4319/lo.1990.35.7.1545

Kuypers, M. M. M., Lavik, G., Woebken, D., Schmid, M., Fuchs, B. M., Amann, R., et al. (2005) Massive nitrogen loss from the Benguela upwelling system through anaerobic ammonium oxidation. Proc. Natl. Acad. Sci. U.S.A. 102, 6478-6483. doi: 10.1073/pnas.0502 088102

Kuypers, M. M. M., Sliekers, A. O. Lavik, G., Schmid, M., Jørgensen, B. B., Kuenen, J. G., et al. (2003) Anaerobic ammonium oxidation by annamox bacteria in the Black Sea Nature 422, 608-611. doi: 10.1038/ nature 01472

Lam, P., Lavik, G., Jensen, M. M., van de Vossenberg, J., Schmid, M. Woebken, D., et al. (2009). Revising the nitrogen cycle in the Peruvian oxygen minimum zone. Proc. Natl. Acad. Sci. U.S.A. 106, 4752-4757. doi: 10.1073/pnas.0812444106

Liu, X., Tiquia, S. M., Holguin, G., Wu, L., Nold, S. C., Devol, A. H., et al. (2003). Molecular diversity of denitrifying genes in continental margin sediments within the oxygen-deficient zone off the Pacific coast of Mexico. Appl. Environ. Microbiol. 69, 3549-3560. doi: 10.1128/AEM.69.6.3549-3560.2003

Maddison, D. R., and Maddison, W. P. (2003). MacClade 4: Analysis of Phylogeny and Character Evolution, Version 4.06. Sunderland, MA Sinauer Associates.

McCune, B., and Grace, J. B. (2002). Analysis of Ecological Communities. Gleneden Beach, OR: MjM Software Design.
McCune, B., and Medford, M. J. (1999). PC-ORD: Multivariate Analysis of Ecological Data, Version 4. Gleneden Beach, OR: MjM Software Design.

Mosier, A. C., and Francis, C. A. (2008) Relative abundance of ammoniaoxidizing archaea and bacteria in the San Francisco Bay estuary. Environ. Microbiol. 10, 3002-3016. doi: 10.1111/j.1462-2920.2008.01764.x

Mosier, A. C., and Francis, C. A. (2010). Denitrifier abundance and activity across the San Francisco Bay estuary. Environ. Microbiol. Rep. 2, 667-676. doi: 10.1111/j.17582229.2010.00156.x

Nogales, B., Timmis, K. N., Nedwell, D. B., and Osborn, A. M (2002). Detection and diversity of expressed denitrification genes in estuarine sediments after reverse transcription-PCR amplification from mRNA. Appl. Environ. Microbiol. 68, 5017-5025. doi: $\quad 10.1128 /$ AEM.68.10.5017 5025.2002

Oakley, B. B., Francis, C. A., Roberts, Fuchsman, C., Srinivasan, S., and Staley, J. T. (2007). Analysis of nitrite reductase (nirK and nirS) genes and cultivation reveal depauperate community of denitrifying bacteria unique to the Black Sea suboxic zone. Environ. Microbiol. 9, 118-130. doi: 10.1111/j.14622920.2006.01121.x

Parsons, T. R., Maita, Y., and Lalli, C. M. (1984). A Manual of Chemical and Biological Methods for Seawater Analysis. Elmsford, NY: Pergamon Press.

Prieme, A., Braker, G., and Tiedje, G. M. (2002). Diversity of nitrite reductase (nirK and nirS) gene fragments in forested upland and wetland soils. Appl. Environ. Microbiol. 68, 1893-1900. doi: 10.1128/AEM.68.4.1893-1900.2002

Rich, J. J., Dale, O. R., Song, B. K., and Ward, B. B. (2008). Anaerobic ammonium oxidation (anammox) in Chesapeake Bay sediments. Microb. Ecol. 55, 311-320. doi: 10.1007/s00248-007-9277-3

Risgaard-Petersen, N., Meyer, R. L., Schmid, M. C., Jetten, M. S. M., Enrich-Prast, A., Rysgaard, S., et al. (2004). Anaerobic ammonia oxidation in an estuarine sediment. Aquat. Microb. Ecol. 36, 293-304. doi: 10.3354/ame036293

Rösch, C., Mergel, A., and Bothe, H. (2002). Biodiversity of denitrifying and dinitrogen-fixing bacteria in an acid forest soil. Appl. Environ. Microbiol. 68, 3818-3829. doi: 10.1128/AEM.68.8.3818-3829. 2002 
Santoro, A. E., Boehm, A. B., and Francis, C. A. (2006). Denitrifier community composition along a nitrate and salinity gradient in a coastal aquifer. Appl. Environ. Microbiol. 72, 2102-2109. doi: 10.1128/AEM.72.3.2102-2109.2006

SAS Institute. (2002). JMP User's Guide. Cary, NC: SAS Institute.

Schloss, P. D., Westcott, S. L., Ryabin, T., Hall, J. R., Hartmann, M., Hollister, E. B., et al. (2009). Introducing MOTHUR: opensource, platform-independent, community-supported software for describing and comparing microbial communities. Appl. Environ. Microbiol. 75, 7537-7541. doi: 10.1128/AEM.01541-09

Seitzinger, S., Harrison, J. A., Bohlke, J. K., Bouwman, A. F., Lowrance, R., Peterson, B., et al. (2006). Denitrification across landscapes and waterscapes: a synthesis. Ecol. Appl. 16, 2064-2090. doi: 10.1890/1051-0761(2006)016[2064: DALAWA]2.0.CO;2

Sharma, S., Aneja, M. K., Mayer, J., Munch, J. C., and Schloter, M. (2005). Diversity of transcripts of nitrite reductase genes (nirK and nirS) in rhizospheres of grain legumes. Appl. Environ. Microbiol. 71, 2001-2007. doi: 10.1128/AEM.71.4.2001-2007.2005

Smith, J. M., and Ogram, A. (2008). Genetic and functional variation in denitrifier populations along a short-term restoration chronosequence. Appl. Environ.
Microbiol. 74, 5615-5620. doi: 10.1128/AEM.00349-08

Smouse, P. E., Long, J. C., and Sokal, R. R. (1986). Multiple regression and correlation extensions of the Mantel Test of matrix correspondence. Syst. Zool. 35, 627-632. doi: $10.2307 / 2413122$

Song, B., and Ward, B. B. (2002). Nitrite reductase genes in halobenzoate degrading denitrifying bacteria. FEMS Microbiol. Ecol. 43, 349-357. doi: 10.1111/j.15746941.2003.tb01075.x

Taroncher-Oldenburg, G., Griner, E. M., Francis, C. A., and Ward, B. B. (2003). Oligonucleotide microarray for the study of functional gene diversity of the nitrogen cycle in the environment. Appl. Environ. Microbiol. 69, 1159-1171. doi: 10.1128/AEM.69.2. 1159-1171.2003

Thompson, J. D., Gibson, T. J., Plewniak, F., Jeanmougin, F., and Higgins, D. G. (1997). The ClustalX windows interface: flexible strategies for multiple sequence alignment aided by quality analysis tools. Nucleic Acid Res. 24, 4876-4882. doi: 10.1093/nar/25.24. 4876

Trimmer, M., Nicholls, J. C., Morley, N., Davies, C. A., and Aldridge, J. (2005). Biphasic behavior of anammox regulated by nitrite and nitrate in an estuarine sediment. Appl. Environ. Microbiol. 71, 1923-1930. doi: 10.1128/AEM.71.4.1923-1930. 2005
Ward, B. B., Devol, A. H., Rich, J. J., Chang, B. X., Bulow, S. E., Naik, H., et al. (2009). Denitrification as the dominant nitrogen loss process in the Arabian Sea. Nature 461, 78-82. doi: 10.1038/nature08276

Ward, B. B., Eveillard, D., Kirshtein, J. D., Nelson, J. D., Voytek, M. A., and Jackson, G. A. (2007). Ammonia-oxidizing bacterial community composition in estuarine and oceanic environments assessed using a functional gene microarray. Environ. Microbiol. 9, 2522-2538. doi: $\quad 10.1111 /$ j.1462-2920.2007. 01371.x

Yan, T., Fields, M. W., Wu, L., Zu, Y., Tiedje, J. M., and Zhou, J. (2003). Molecular diversity and characterization of nitrite reductase gene fragments (nirK and nirS) from nitrate- and uranium-contaminated groundwater. Environ. Microbiol. 5, 13-24. doi: 10.1046/j.1462-2920. 2003.00393.x

Yoshie, S., Noda, N., Tsuneda, S., Hirata, A., and Inamori, Y. (2004). Salinity decreases nitrite reductase gene diversity in denitrifying bacteria of wastewater treatment systems. Appl. Environ. Microbiol. 70, 3152-3157. doi: 10.1128/AEM.70. 5.3152-3157.2004

Zhou, J., Fries, M. R., Chee-Sanford, J., and Tiedje, J. M. (1995). Phylogenetic analyses of a new group of denitrifiers capable of anaerobic growth on toluene and description of Azoarcus tolulyticus sp. nov. Int. J. Syst. Bacteriol. 45,
500-506. doi: 10.1099/0020771345-3-500

Zumft, W. G. (1997). Cell biology and molecular basis of denitrification. Microbiol. Mol. Biol. Rev. 61, 533-616.

Conflict of Interest Statement: The authors declare that the research was conducted in the absence of any commercial or financial relationships that could be construed as a potential conflict of interest.

Received: 18 July 2012; accepted: 30 July 2013; published online: 30 August 2013.

Citation: Francis CA, O'Mullan GD, Cornwell JC and Ward BB (2013) Transitions in nirS-type denitrifier diversity, community composition, and biogeochemical activity along the Chesapeake Bay estuary. Front. Microbiol. 4:237. doi: 10.3389/fmicb. 2013.00237

This article was submitted to Aquatic Microbiology, a section of the journal Frontiers in Microbiology.

Copyright (C) 2013 Francis, O'Mullan, Cornwell and Ward. This is an openaccess article distributed under the terms of the Creative Commons Attribution License (CC BY). The use, distribution or reproduction in other forums is permitted, provided the original author(s) or licensor are credited and that the original publication in this journal is cited, in accordance with accepted academic practice. No use, distribution or reproduction is permitted which does not comply with these terms. 